\title{
Instruments to assess the perception of physicians in the decision-making process of specific clinical encounters: a systematic review
}

\author{
France Légaré*1,2, David Moher ${ }^{3}$, Glyn Elwyn ${ }^{4}$, Annie LeBlanc ${ }^{1}$ and \\ Karine Gravel ${ }^{1}$
}

Address: ${ }^{1}$ Research Centre of the Centre Hospitalier Universitaire de Québec, Québec, Canada, ${ }^{2}$ Department of Family Medicine, Université Laval, Québec, Canada, ${ }^{3}$ Department of Epidemiology \& Community Medicine, Faculty of Medicine, University of Ottawa, Ottawa, Canada and ${ }^{4}$ Department of General Practice, Centre for Health Sciences Research, Cardiff University, Cardiff, Wales, UK

Email: France Légaré* - france.legare@mfa.ulaval.ca; David Moher - dmoher@uottawa.ca; Glyn Elwyn - elwyng@cardiff.ac.uk; Annie LeBlanc - annie.leblanc.7@ulaval.ca; Karine Gravel - karine.gravel@crsfa.ulaval.ca

* Corresponding author

Published: 15 October 2007

BMC Medical Informatics and Decision Making 2007, 7:30 doi:10.1 I86/1472-6947-7-30
Received: 20 April 2007

Accepted: 15 October 2007

This article is available from: http://www.biomedcentral.com/I472-6947/7/30

(C) 2007 Légaré et al.; licensee BioMed Central Ltd.

This is an Open Access article distributed under the terms of the Creative Commons Attribution License (http://creativecommons.org/licenses/by/2.0), which permits unrestricted use, distribution, and reproduction in any medium, provided the original work is properly cited.

\begin{abstract}
Background: The measurement of processes and outcomes that reflect the complexity of the decision-making process within specific clinical encounters is an important area of research to pursue. A systematic review was conducted to identify instruments that assess the perception physicians have of the decision-making process within specific clinical encounters.

Methods: For every year available up until April 2007, PubMed, PsycINFO, Current Contents, Dissertation Abstracts and Sociological Abstracts were searched for original studies in English or French. Reference lists from retrieved studies were also consulted. Studies were included if they reported a self-administered instrument evaluating physicians' perceptions of the decision-making process within specific clinical encounters, contained sufficient description to permit critical appraisal and presented quantitative results based on administering the instrument. Two individuals independently assessed the eligibility of the instruments and abstracted information on their conceptual underpinnings, main evaluation domain, development, format, reliability, validity and responsiveness. They also assessed the quality of the studies that reported on the development of the instruments with a modified version of STARD.
\end{abstract}

Results: Out of 343I records identified and screened for evaluation, 26 potentially relevant instruments were assessed; II met the inclusion criteria. Five instruments were published before 1995. Among those published after 1995, five offered a corresponding patient version. Overall, the main evaluation domains were: satisfaction with the clinical encounter $(n=2)$, mutual understanding between health professional and patient $(n=2)$, mental workload $(n=1)$, frustration with the clinical encounter $(n=1)$, nurse-physician collaboration $(n=1)$, perceptions of communication competence $(n=2)$, degree of comfort with a decision $(n=1)$ and information on medication $(n=1)$. For most instruments $(n=10)$, some reliability and validity criteria were reported in French or English. Overall, the mean number of items on the modified version of STARD was I2.4 (range: 2 to I8).

Conclusion: This systematic review provides a critical appraisal and repository of instruments that assess the perception physicians have of the decision-making process within specific clinical encounters. More research is needed to pursue the validation of the existing instruments and the development of patient versions. This will help researchers capture the complexity of the decision-making process within specific clinical encounters. 


\section{Background}

Practising medicine involves making decisions at all stages of the clinical process [1]. Although a great deal of varied terminology is used to describe doctors' thinking, the term "decision-making process" is used extensively in the medical and healthcare literature [2]. The decisionmaking process is broadly defined as global judgements by a clinician about the appropriate course of action and is said to be unspecified, as a number of processes may produce a decision [3]. In clinical settings, it is also understood as the use of diverse strategies to generate and test potential solutions to problems that are presented by patients and involves using, acquiring and interpreting the indicators and then generating and evaluating hypotheses [4]. Processes or strategies that will be used may be based on what the clinician was taught, his or her own representation of the evidence supporting each course of action, or the prevailing practice in a given institution [4].

In recent years, there has been a growing interest in new representations of the clinical decision-making process that better address its complexity within specific clinical encounters. Indeed, providing medical care to a patient is now increasingly considered a dynamic and interactive process known as "shared decision-making" [5-7]. Characteristics of shared decision-making include that at least two participants, clinician and patient, be involved; that there be a two-way exchange not only of information but also of treatment preferences; that both parties take steps to build a consensus about the preferred treatment; and that an agreement be reached on the treatment to be implemented [5]. Shared decision-making includes the following components: establishing a context in which patients' views about treatment options are valued and deemed necessary, transferring technical information, making sure patients understand this information, helping patients base their preference on the best evidence; eliciting patients' preferences, sharing treatment recommendations, and making explicit the component of uncertainty in the clinical decision-making process [8].

Shared decision-making does not exclude a consideration of the values and preferences of the physician and occurs through a partnership in which the responsibilities and rights of each of the parties and the benefits for each party are made clear [9]. Given the recognition that patient-physician interactions and by extension, clinical decisionmaking processes, are dynamic and reciprocal in their nature, it is surprising to find little systematic evaluation of the physicians' perspective of this entity [10]. Consequently, there has been a renewed interest in capturing the perspective of physicians of the decision-making process within specific clinical encounters. Therefore, the aim of this systematic review was to identify instruments that assess the perception of physicians of the decision-making process within specific clinical encounters.

\section{Methods \\ Search strategy}

Covering all years available (to April 2007), we conducted an electronic literature search of the following databases: PubMed, PsycINFO, Current Contents, Dissertation Abstracts and Sociological Abstracts. Three information specialists were consulted to help develop, update and run the search strategy. The following MeSH terms and free text words were used to create specific search strategies for each database: "decision making", "physicians", "health personnel", "doctors", "practitioners", "health personnel attitudes", "measurement", "questionnaire", "psychometrics" and "psychological tests". We included titles of publications and their respective abstract in English or French that potentially included an eligible instrument. Initially, if a dissertation abstract was found along a publication, both were kept. We also contacted 10 experts in the field (list available from authors) and contacted corresponding authors of included instruments. Lastly, we reviewed bibliographies of the included instruments. Once we included an instrument, we conducted an electronic search of the first author.

\section{Selection criteria}

All of the searches were downloaded to a reference database for initial screening of titles and abstracts by a single member of the review team. Prior to screening, duplicates were removed from the database. Titles of publications and their respective abstract reporting editorials, letters, surveys, clinical vignettes or the completion of an Objective Structured Clinical Examination or the evaluation of a simulated patient were excluded. After the initial screening, if detailed information about the titles of publications and their respective abstract was questionable, the full text of these publications was sought. Then, two reviewers independently appraised these publications to identify ones that reported on the use or development an eligible instrument. Discrepancies between the two reviewers were resolved through discussion.

\section{Identification of eligible instruments}

The following inclusion criteria were applied: 1) a selfadministered instrument was presented; 2) the instrument evaluated the perspective of physicians, including residents, of the decision-making process within specific clinical encounters, 3 ) the collection of data occurred after a specific clinical encounter in a 'real' clinical setting; 4) the report included sufficient description to permit critical appraisal of the instrument (for example, the instrument was provided as an appendix or we were able to get a copy from the author); and 5) there were quantitative results following the administration of the instrument. An instru- 
ment was defined as a systematic procedure for the assignment of numbers to aspects of objects, events or persons as indicated by its construction, administration and scoring procedure according to prescribed rules [11].

The outcomes of interest included the perception of physicians of the decision-making process within specific clinical encounters as well as the outcome of the decision itself such as satisfaction with the decision. The decisionmaking process was defined in an inclusive manner as global judgements by a physician about the appropriate course of action [3]. An instrument was deemed eligible if one of its sub-scales or some of its items tapped into the outcomes of interest.

\section{Data extraction}

The data extraction form, derived from McDowell (1987) [12], covered characteristics of the source of information and characteristics of the instrument itself, such as name of the instrument, origin of first author, main purpose, description of the instrument, characteristics of the response scale, presence of a corresponding patient instrument, development procedures, conceptual/theoretical foundation, validity, reliability (e.g. internal consistency) and responsiveness of the instrument.

A conceptual framework was considered to be used if the author referred to a set of concepts and the propositions that integrate them into a meaningful configuration [13]. A theory was deemed to be used if the author referred to a theory, defined as a series of statements that purport to account for or characterize some phenomenon with a much greater specificity that a conceptual framework [13]. Otherwise, the nature of the source of references used by the author was used to identify a broad conceptual basis.

Content validity (i.e. the extent to which all relevant aspects of the domain or area that is being measured are represented in the instrument), construct validity (i.e. the extent to which the instrument relates to other tests or constructs in the way that was expected) and criterion validity (i.e. the extent to which the instrument relates to a gold standard to which it is compared) were also assessed [14]. Responsiveness (i.e. the extent to which the instrument measured change within persons over time) was also assessed [15].

Using the Science Citation Index, we assessed how many times the included instruments had been cited in subsequent published research in French or English. Lastly, for each instrument, we assigned one main evaluation domain defined as a subjective interpretation by the reviewers of the main construct that the instrument was assessing. Sources of disagreement were discussed and resolved by consensus and only consensus data was used.
Data extraction was completed by two members of the team.

\section{Quality assessment}

The quality of reporting of the included studies was assessed by two reviewers independently, using a modified version of the following instrument, Standards for Reporting of Diagnostic Accuracy (STARD) [16-18]. The original STARD contains 25 items pertaining to study question, study participants, study design, test methods, reference standard, statistical methods, reporting of results and conclusions. However, because we were interested in instruments assessing the perception of physicians of the decision-making process within specific clinical encounters, we added one more item under the section "statistical methods." This new item assessed if the authors of the included instrument had taken into account that one physician could only contribute to one questionnaire for the statistical analyses used to provide evidence on its reliability and validity (i.e., the non-independence of data). For each instrument, we chose one main study. In instruments for which more than one report was included, we chose the one that reported the most details on the development and psychometrics of the instrument in its most recent version.

\section{Results}

\section{Included instruments}

The initial search resulted in 3431 records (Figure 1). From these, 192 records that were in a language other than French or English, and 138 duplicates were removed. After applying our eligibility criteria, 218 full text articles were retrieved for detailed evaluation. Twenty-six instruments (67 articles) were potentially eligible of which a further 15 (28 articles) were excluded because they were not designed to collect data for a specific clinical encounter [19-46]. Therefore, 11 instruments (39 articles) were included [47-85]. We were able to get access to a published version or a copy of all included instruments.

\section{Characteristics of the included instruments}

Overall, the included instruments were published between 1986 and 2007 (Table 1) [47-85]. Nine instruments were developed in North America and available in English [47-67,69-72,74-85]. Among these, three were available in French $[57,58,64-67,69-71,77-82]$. Two instruments were developed in Europe $[68,73]$. For most instruments, the first author was affiliated with a Faculty of Medicine or a medical organisation $(n=8)[54-59,64$ $72,74,76-85$ ], followed by a School of Nursing $(n=1)$ [47-53,75], Department of Communication $(n=1)$ [6063] and Research Group in Psychosomatic Rehabilitation $(\mathrm{n}=1)$ [73]. Most instruments were developed for nonspecific clinical problems $(\mathrm{n}=9)$ [54-74,76,83-85]. One instrument was developed for intensive care unit-related 


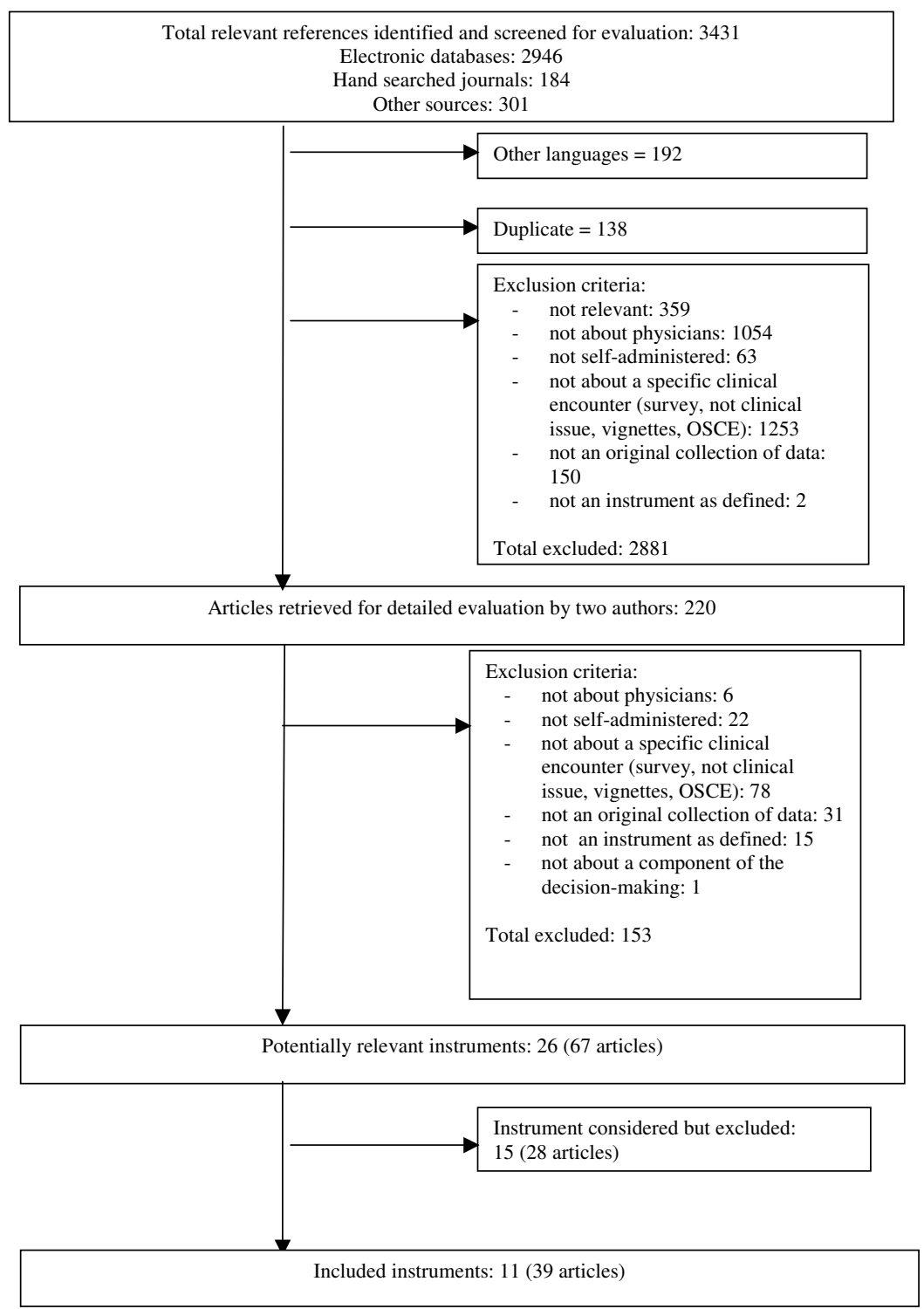

Figure I

Progress through the stages of the systematic review.

problems $[47-53,75]$ and one for inflammatory bowel diseases [77-82].

All instruments were multi-dimensional. The mean number of items per instrument was 16.7 (range: 6 to 37). Seven instruments used a Likert response scale [47$54,57,58,60-67,69-72,75,76,83-85]$, two used a Visual Analog Scale [55,56,59,74,77-82] and one used a 5-point categorical response scale [73]. One instrument used a mix of response scales [68]. Five instruments offered a patient version $[57,58,60-71,77-82]$.

Based on the Science Citation Index, nine instruments had been cited at least once in subsequent research pub- lished in French or English with the older ones being more likely to be cited more often (Spearman $\mathrm{r}=-0.68 ; \mathrm{p}$ $=0.03$ ).

\section{Development procedures and psychometrics of the included instruments}

Authors of nine instruments reported on their explicit use of some conceptual framework or broad conceptual domain (Table 2) [47-53,55-75,77-82]. For seven instruments, we were able to find evidence of their validity and reliability [47-67,69-71,74-76,83-85]. For two instruments, evidence of validity and reliability data was available only for the combined use of the physician's and patient's questionnaires [68,77-82]. For one instrument, 
Table I: Characteristics of the II included instruments

\begin{tabular}{|c|c|c|c|c|c|c|}
\hline $\begin{array}{l}\text { Name of the } \\
\text { instrument } \\
\text { (First author, year of } \\
\text { publication) }\end{array}$ & Origin of first author & $\begin{array}{l}\text { Main purpose (Measurement aim, clinical domain and } \\
\text { context of use envisioned by author) }\end{array}$ & $\begin{array}{l}\text { Description } \\
\text { (number of dimensions and items) }\end{array}$ & $\begin{array}{l}\text { Response } \\
\text { scale }\end{array}$ & $\begin{array}{l}\text { Patient } \\
\text { version }\end{array}$ & $\begin{array}{c}\text { Number } \\
\text { of } \\
\text { citations }\end{array}$ \\
\hline $\begin{array}{l}\text { Physician Satisfaction } \\
\text { Scale } \\
\text { (Shore, 1986) }[54,76,83]\end{array}$ & $\begin{array}{l}\text { Department of } \\
\text { Preventive, Family and } \\
\text { Rehabilitation Medicine }\end{array}$ & $\begin{array}{l}\text {-To study physician satisfaction in encounter-specific situations. } \\
\text {-Non-specific clinical problem. } \\
\text {-Clinical and educational (the authors thought that the use of } \\
\text { this instrument could serve as a possible pathway to changing } \\
\text { providers' behaviour through self-awareness). }\end{array}$ & $\begin{array}{l}-2 \text { dimensions/ } / 6 \text { items } \\
\text {-understanding the patient's problem, having } \\
\text { a sense that the patient understood what the } \\
\text { physician said, affective reactions to the } \\
\text { interaction with the patient and satisfaction } \\
\text { of physician and patient were included. }\end{array}$ & 5 pt Likert & No & 14 \\
\hline $\begin{array}{l}\text { Mental Work-Load } \\
\text { Instrument } \\
(\text { Bertram, 1992) } \\
{[55,56,59,74]}\end{array}$ & $\begin{array}{l}\text { Department of Social } \\
\text { and Preventive Medicine }\end{array}$ & $\begin{array}{l}\text {-To assess the subjective experience or cost incurred by a } \\
\text { physician in performing patient care tasks that reflect the } \\
\text { combined effect of demands imposed by task requirements, } \\
\text { the support personnel, information and equipment resources } \\
\text { provided the physician's skill and experience, strategies } \\
\text { adopted by the physician, effort exerted, and emotional } \\
\text { responses to the situation. } \\
\text {-Non-specific clinical problem. } \\
\text {-Quality improvement (the authors aimed at taking into } \\
\text { account the cognitive processes involved in physician work so } \\
\text { that physicians could be trained or patient care settings } \\
\text { structured to minimize the physician limitations and improve } \\
\text { their performance as well as the productivity of the } \\
\text { organization). }\end{array}$ & $\begin{array}{l}-5 \text { dimensions } / 6 \text { items } \\
\text {-mental effort, physical effort, difficulty, } \\
\text { performance and psychological stress } \\
\text { (each with I item except performance with } \\
\text { 2). }\end{array}$ & $\begin{array}{l}0.0-10.0 \\
\text { visual analogue } \\
\text { scale with } \\
\text { bipolar } \\
\text { descriptors. }\end{array}$ & No & 8 \\
\hline $\begin{array}{l}\text { Questionnaire concerning } \\
\text { the sources of frustration } \\
\text { physicians experience in } \\
\text { their work with patients } \\
\text { (Levinson, 1993) [72] }\end{array}$ & Department of Medicine & $\begin{array}{l}\text {-To identify specific aspects of patient visits that cause } \\
\text { physician frustration and to develop a self-assessment } \\
\text { instrument for physicians } \\
\text {-Non-specific clinical problem. } \\
\text {-Quality improvement (the authors thought that through } \\
\text { reflection, this instrument would assist physicians to identify } \\
\text { areas of their experience with patients that are frustrating and } \\
\text { that need improvement and that ultimately, patient care would } \\
\text { be improved). }\end{array}$ & $\begin{array}{l}-7 \text { dimensions } / 25 \text { items } \\
\text {-lack of trust, too many problems, feeling } \\
\text { distressed, lack of adherence, lack of } \\
\text { understanding, demanding/controlling } \\
\text { patients, and special problems (each with 3-4 } \\
\text { items). }\end{array}$ & 5 pt Likert & No & 49 \\
\hline $\begin{array}{l}\text { Physician Satisfaction } \\
\text { Questionnaire } \\
\text { (Suchman, 1993) }[84,85]\end{array}$ & $\begin{array}{l}\text { Department of Medicine } \\
\text { and Psychiatry }\end{array}$ & $\begin{array}{l}\text {-To assess physician satisfaction with primary care office visits } \\
\text { in encounter-specific contexts, and to identify determinants of } \\
\text { physician satisfaction. } \\
\text { - Non-specific clinical problem. } \\
\text { - Research, clinical and educational (the authors thought that } \\
\text { this instrument could be used to guide the preparation of } \\
\text { future physicians with skills, knowledge and attitudes they will } \\
\text { need to practice in a manner that is satisfying both to their } \\
\text { patients and to themselves). }\end{array}$ & $\begin{array}{l}-4 \text { dimensions/ } 20 \text { items } \\
\text {-quality of the patient doctor relationship, } \\
\text { adequacy of the data collection process } \\
\text { during the visit, appropriate use of time } \\
\text { during the visit and patient's non-demanding, } \\
\text { cooperative nature. }\end{array}$ & 5 pt Likert & No & 44 \\
\hline $\begin{array}{l}\text { Medical Communication } \\
\text { Competence Scale } \\
\text { (Cegala, 1998) [60-63] }\end{array}$ & $\begin{array}{l}\text { Department of } \\
\text { Communication }\end{array}$ & $\begin{array}{l}\text {-To measure doctor's and patient's perceptions of self and } \\
\text { other communication competence during a general medical } \\
\text { interview. } \\
\text {-Non-specific clinical problem. } \\
\text {-Research. }\end{array}$ & $\begin{array}{l}-4 \text { dimensions/37 items } \\
\text {-information giving, seeking and verifying and } \\
\text { socio emotional communication. }\end{array}$ & 7 pt Likert & Yes & 10 \\
\hline
\end{tabular}


Table I: Characteristics of the II included instruments (Continued)

\begin{tabular}{|c|c|c|}
\hline $\begin{array}{l}\text { Provider Decision } \\
\text { Process Assessment } \\
\text { Instrument } \\
\text { (Dolan, 1999) } \\
{[57,64-67,69-71]}\end{array}$ & Department of Medicine & $\begin{array}{l}\text {-To measure physicians' degree of comfort with a clinical } \\
\text { treatment decision. } \\
\text {-Non-specific clinical problem. } \\
\text {-Quality improvement and research (The author asserts that } \\
\text { combining it with an equivalent patient-oriented measure } \\
\text { would make it possible to comprehensively assess the clinical } \\
\text { decision making process). }\end{array}$ \\
\hline $\begin{array}{l}\text { Patient-Physician } \\
\text { Discordance Scale } \\
\text { (Sewitch, 2003) [77-82]. }\end{array}$ & Department of Medicine & $\begin{array}{l}\text {-To assess discordance between physicians and their patients } \\
\text { on evaluations of health-related information. } \\
\text {-Chronic diseases, most specifically inflammatory bowel } \\
\text { diseases. } \\
\text {-Clinical and research. }\end{array}$ \\
\hline $\begin{array}{l}\text { Mutual Understanding } \\
\text { Scale } \\
\text { (Harmsen, 2005) [68] }\end{array}$ & $\begin{array}{l}\text { Department of Health } \\
\text { policy and management } \\
\text { and Department of } \\
\text { general practice }\end{array}$ & $\begin{array}{l}\text {-To develop a reliable measure of mutual understanding } \\
\text { between general practitioners and patients. } \\
\text {-Non-specific clinical problem. } \\
\text {-Research or professional training. }\end{array}$ \\
\hline $\begin{array}{l}\text { Reasons for Treatment } \\
\text { Selection Questionnaire } \\
\text { (Linden, 2006) [73] }\end{array}$ & $\begin{array}{l}\text { Research Group } \\
\text { Psychosomatic } \\
\text { Rehabilitation }\end{array}$ & $\begin{array}{l}\text {-To assess reasons why physicians select or do not select a } \\
\text { certain treatment. } \\
\text {-Non-specific clinical problem. } \\
\text {-N/A }\end{array}$ \\
\hline $\begin{array}{l}\text { Questionnaire concerning } \\
\text { the doctor-patient } \\
\text { communication skills } \\
\text { (Campbell, 2007) [58] }\end{array}$ & $\begin{array}{l}\text { Royal College of } \\
\text { Physicians and Surgeons } \\
\text { of Canada }\end{array}$ & $\begin{array}{l}\text { - To develop and psychometrically assess the feasibility, } \\
\text { reliability and validity of an assessment tool in which both } \\
\text { doctor and patient perceptions of the communication that } \\
\text { occurred in a single office visit are captured. } \\
\text { - Non-specific clinical problem in general practice and medical } \\
\text { specialists practice. } \\
\text { - Designed for use in the office settings. }\end{array}$ \\
\hline
\end{tabular}

-4 dimensions//2 items

-uncertainty, knowledge, value, effectiveness.

5 pt Likert

Yes

7

Note: the English version of the

questionnaire was translated into French by a professional translator and then back-

translated into English by a family physician

who was not associated with the authors.

-3 dimensions/ 10 items

00-mm visual

-symptoms and treatment, well-being and

analogue scale

communication and satisfaction.

Note: the English version of th

questionnaire was translated into French by

an independent bilingual medical translator and a bilingual psychology student, and the back-translated into English by two other bilingual graduate students who were not

associated with the authors.

-3 dimensions/8 criteria

-perception of one's own ability to explain to the patient, perception of the patient's ability to explain to the physician, and perception of patient's understanding of consultation

aspects.

-5 dimensions $/ 22$ items

-theoretical knowledge, experiential knowledge, situational knowledge, anticipations about the further course of treatment, and interactional knowledge

- 2 dimensions/ 19 items

- The final instrument captures both the process aspects of the visit (e.g. patient greeting, listening, and understanding) as well as the content of the visit (e.g. explanations, treatment options, next steps). 


\begin{tabular}{|c|c|c|c|c|}
\hline Instrument & Origins and development & Conceptual framework & Validity & Reliability \\
\hline $\begin{array}{l}\text { Physician Satisfaction Scale } \\
\text { (Shore, 1986) }[54,76,83]\end{array}$ & $\begin{array}{l}\text { Delphi method with family physicians to develop first } \\
43 \text {-item version on } 4 \text { sub-scales. Tested on } 49 \\
\text { physicians. The scale was then reduced to } 16 \text { items on } \\
\text { two sub-scales and tested back on } 13 \mathrm{I} \text { physicians } \\
\text { from Family Medicine, General Internal Medicine and } \\
\text { Paediatric programs. }\end{array}$ & Not clear & $\begin{array}{l}\text { Content validity: } \\
\text {-efforts were put in the development phase of the } \\
\text { instrument to ensure validity of the items } \\
\text { (consultation with Delphi method). } \\
\text { Construct validity: } \\
\text {-factor analysis confirms two factors (average loading } \\
\text { for patient-related: } 0.7 \text { I and average loading for } \\
\text { contextual: } 0.58 \text { ) } \\
\text {-the instrument did not discriminate between } \\
\text { different residency programs, geographical location }\end{array}$ & $\begin{array}{l}\text { Internal consistency } \\
\text {-Cronbach alpha for } \\
\text { global scale: } 0.85 \\
\text { (patient-related } \\
\text { subscale: } 0.89 \text { and } \\
\text { contextual subscale: } \\
0.63 \text { ) }\end{array}$ \\
\hline
\end{tabular}

Physician Mental Workload (Bertram, 1992) $[55,56,59,74]$

A previous version of the instrument was constructed by 1076 physicians. Final version consists of 25 items on 7 sub-scales. through discussion with physicians and from a preliminary literature search. It was tested in two different hospital settings and revisions led to a 10 item version also presented on a visual analogue scale. The present instrument is a 6-item adaptation of this previous one. It was tested on 22 residents, who in all saw a total of 92 patients during an afternoon clinic session. It was tested with residents and physicians in practice, internal medicine and very few in paediatric residency

Broad domain of human performance research and measurement approaches employed in the field of human factors research. It encompasses motivational, social, attitudinal, and organizational factors as well as human capability assessment information processing and decision making and stress effects on performance.

A group of experts developed an initial set of 32 items corresponding to common problems encountered by physicians in their encounters with patients. This was pilot-tested on 107 physicians of diverse trainings. A second version of 42 items on 8 sub-scales was distributed to 931 physicians, and was reduced to 39 items, and this version was completed
Broad domain pertaining to the quality of the communication and the relationship between patients and their physicians as important pathways to both the medical

outcome and satisfaction of both parties. different residency programs, geographical location or years of training.

Content validity:

-efforts have been made in the development of the first version of the instrument to ensure face validity by consulting physicians, and formal content validity by literature review. The process of selection of the items included in the present version is not described.

Construct validity:

-correlates with: fatigue: $r=0.42$, mean experience, $r$ $=-0.65$, resident self-rated quality: $r=-0.67$, third observer's overall quality rating, $r=-0.18$, personal interaction factor score: $r=-.04$, technical performance factor score: $r=-0.38$ -does not correlate with: total number of patients seen, proportion of new patients, patient complexity, personal interaction performance, overall ratings by faculty members and age of the residents. -does not discriminate between female and male residents nor among postgraduate years.

Note: In order to not violate the assumption of independence between observations, the unit of analysis chosen was the resident, and an associated average score per resident was used with patientspecific measures.

Content validity:

-efforts were put into the development phase of the instrument to ensure validity of the items ( $x$

consultation of experts) Construct validity:

-factor analysis confirms 7 factors. Mean respective factor loading for all items is $0.68(S D=0.10)$ -the instrument discriminated between younger and older physicians (i.e. younger physicians had higher scores on all subscales meaning they felt more frustrated than the older physicians) and between primary care physicians and specialists on two subscales: too many problems and feeling distressed (i.e. primary care physicians had higher score than specialists). Greater time spent in primary care was associated with higher scores on several subscales. Convergent validity was shown with physicians' general level of satisfaction and the percentage of visits they reported as being frustrating correlating with higher scores on most subscales.
Internal consistency : -Cronbach alpha: 0.80 (unadjusted for nonindependence of observation) -Inter-items correlation: mean: 0.45 (SD.: 0.19)

Not provided 
Table 2: Development and psychometric properties of the II included instruments (Continued)

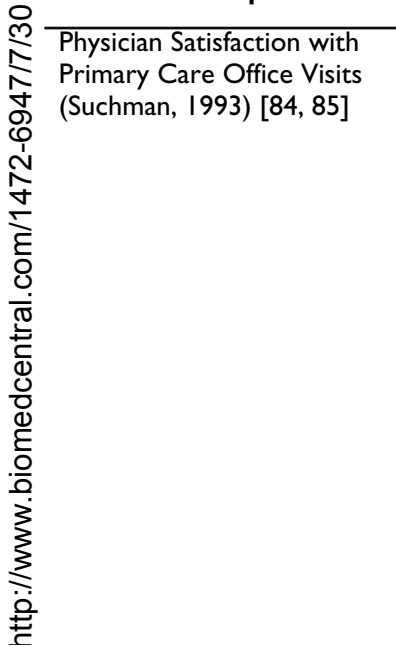

Collaboration and Satisfaction about Care Decisions (Baggs, 1994) [49-53, 75]
The development of this instrument was achieved

within a larger initiative, "The Collaborative Study of Communication Dynamics". This initiative was

organized by the Task Force on Doctor and Patient of the Society of General Internal Medicine that was conducted at II sites in North America. Members of this group included well-known experts in the field of patient-doctor interaction and communication. The instrument was tested with 124 physicians (35 residents, 60 general internists and 3 family physicians) who saw a total of 550 patients.

This instrument is based on a conceptual model for collaboration for conflict resolution. It was developed from an initial 2-item version, the Decision About Transfer, a literature review on the subject and opinion of experts in collaborative practice and of practising professionals in the field. It was pilot tested on a convenience sample of 32 nurses and 26

residents in an intensive care unit.
Thomas (1976) conceptual model f collaboration for conflict resolution and organisationa theory by Thompson (1967)
Content validity: face validity is considered in that the items of the scale share common ground with previously published measures

Construct validity:

factor analysis reveals 4 distinct factors, but since these construct domains were not predicted at first in a theoretical framework, this analysis provides weaker support for the construct validity of the instrument

-a number of patient characteristics were significantly associated with the sub-scales. For example, emotional distress of patients was negatively correlated with all satisfaction dimensions except the time dimension. Satisfaction with the patient doctor relationship sub scale was the most important determinant of global satisfaction $\left(R^{2}=39 \%\right)$ while the adequacy of data collection process was the second most important determinant $\left(R^{2}=4 \%\right)$

Note: Non-independence of observations was taken into account: a bootstrapping technique was used to create 10 replication samples of $n=124$ and factor analysis was then performed 10 times.

Content validity:

-literature review on the subject and opinion of experts in collaborative practice and of practising professionals in the field

Construct validity:

-factor analysis confirms a single factor (Eigen value of 4.5 , no other higher than I) that explains $75 \%$ of the 6 specific collaboration items variance. Mean

factor loading for the six specific collaboration items wastor loading for the 0.87 (SD.: 0.04).

-convergence of a combined score of the six specific collaboration items with a combined score of the

two satisfaction items: $r=0.66$

Criterion validity:

-correlation of the six specific collaboration items with the global collaboration question: $r=0.87$ Note: Non-independence of observations was taken into account: factor analysis was performed with a sample size of 56 (i.e. all independent data entry points) and confirmed one factor for collaboration consistency

Cronbach alpha for the

19 specific items

(excluding the genera satisfaction question): 0.82

-Cronbach alpha for all 20 items: 0.84

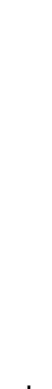

Internal consistency:

-Cronbach's alpha: 0.93

-Inter-item correlations:

$0.52-0.83$ 


\section{Post-interview questionnaires in clinical setting as well} as self and other evaluation of communication competence by 15 family practice residents inspire the development of a first version of 56 items. Six physicians scored each item for their importance to communication competence during a medical consultation. Best items constituted the 37 items final version. A corresponding patient instrument was also pilot-tested concomitantly. Hence, these two

instruments were pilot-tested with 65 doctors and 52

patients who provided a total of 117 data entries.
Provider Decision Process Assessment Instrument 요 instrument is an adaptation of O'Connor's 16-item

Patient Decisional Conflict Scale. Data were obtained on two sites from 14 residents, 7 physicians and one fellow in General Internal Medicine.
Extensive theoretical review supports the development of the scale.

.


Table 2: Development and psychometric properties of the II included instruments (Continued)

This pair of instruments was developed based on the Patient Centered Care method [98] and theories in the field of communication. Its authors drew on existing instruments and the communication skills expertise of 2 members of the steering group to create the pair of instruments. The initial instruments were administered to 4 specialists and 3 family doctors in Ontario, Canada, who, along with their patients, provided feedback. The final pair of instruments was tested with 16 family doctors and 22 pecialists from 3 Canadian provinces. These doctors recruited a total of I88I patients.

N/A: Information is not available in publications in French or English
Patient Centered Care method [98] and theories in the field of communication.
Content validity: based on existing instruments and the communication skills expertise of 2 members of the steering group to create the pair of instruments. Construct validity:

-Factor analysis was performed by using the whole questionnaire plus 19 items in the patient's

questionnaire) to ascertain whether the patient and doctor items were 2 separate factors. Then by examining the data for patient and doctor separately, the authors ascertained if the process and content items accounted for separate factors.

The items on all 3 datasets (i.e. 19 items from the ans 19 items from the doctor alone, and the combined dataset of 38 items) were separately intercorrelated using Pearson product) moment correlations.
Internal consistency:

Cronbach alpha for the doctor and patient questionnaires: 0.7 0.69 , respectively.

Number of patients per doctor required for a reliable assessment of the doctor's overal - The $G$ analysis provided a $G=0.98$ and 0.40 (standard errors of 0.003 and 0.02 ) for doctors and patients, respectively. 
we could not find evidence of validity and reliability data published in French or English [73].

None of the instruments provided data on their responsiveness (i.e. the extent to which it measures change within a physician over time). Lastly, the main evaluation domain that was assigned to each instrument were: satisfaction with the clinical encounter $(n=2)$ [54,76,83-85], mutual understanding between the health professional and the patient $(\mathrm{n}=2)[68,77-82]$, mental workload $(\mathrm{n}=$ 1) $[55,56,59,74]$, frustration with the clinical encounter $(\mathrm{n}=1)$ [72], nurse-physician collaboration $(\mathrm{n}=1)$ [47$53,75]$, perceptions of communication competence $(n=$ 2) $[58,60-63]$, degree of comfort with a decision $(n=1)$ $[57,64-67,69-71]$ and information on medication $(n=1)$ [73].

\section{Quality of the studies that reported on the included instruments}

Overall, the mean number of items reported on the modified STARD was 12.4 (range: 2 to 18$\}$ (Table 3). During the development of four instruments, the authors used an analytical approach that took into account the non-independence of data [47-53,55-57,59,64-67,69$71,74,75,84,85]$. For the Mental Work-Load Instrument, the authors used a mean score per physician to perform the correlation analyses $[55,56,59,74]$. For the Physician Satisfaction Questionnaire, the authors used a bootstrapping approach to perform the factor analysis $[84,85]$. For the Collaboration and Satisfaction about Care Decisions instrument, the authors restricted their sample size to one data entry per physician $(n=56)$ to perform most of their analyses $[47-53,75]$ and for the Provider Decision Process Assessment Instrument, the authors used a bootstrapping approach to perform their reliability analyses (i.e. Cronbach alpha) [57,64-67,69-71].

\section{Discussion}

We believe that the results of this systematic review are important. First, they indicate that there is an interest expressed by clinicians, health services researchers and educators in assessing the perspective of physicians about the processes leading to a decision within specific clinical encounters. This is congruent with the increasing number of randomized trials and systematic reviews examining the efficacy of interventions designed to bring about a change in clinical practice [86]. However, most of these trials assessed a change in health professionals' behaviour without assessing the underlying decision-making process that lead to such behavioural change. This review provides a list of standardized measures of the physician perspective of the clinical decision-making process, an essential step prior to behavioural change. Moreover, most of the included instruments provided some account of their conceptual or theoretical underpinnings. This is important because more attention needs to be given to the combination of different theories that could help us understand professional behaviours [87-90]. Therefore, this review provides health services researchers and educators with a set of standardized and theory-driven instruments that have the potential to improve the quality of implementation studies and by extension our understanding of health professionals' behaviour changes.

Second, this review provides evidence that health services researchers are beginning to use a dyadic and relationship-centered approach to clinical decision-making [9193]. In other words, health services researchers are moving from studying groups of patients and health professionals separately to studying both simultaneously. For example, five of the six most recently developed instruments had corresponding patient versions [57,58,60-71,77$79,81,82]$. Moreover, for the authors of two of these instruments, evidence of validity and reliability data was available only for the combined use of the physician's and patient's questionnaires [68,77-82]. This observation suggests that, increasingly, the clinical decision-making process is perceived as not being dissociable from the complex aspects of interdependence occurring between the physician and the patient. Indeed, the patient-physician relationship is an important component of physicians' satisfaction with their job [93]. Physicians' judgements about their experience with individual patients both reflect and shape what takes place during office visits and beyond [84]. This symmetry supports empirically what has previously been described on the basis of personal needs, namely, that both the physician and the patient have the same human needs for connection which can be fulfilled in the clinical encounter [84]. Therefore, future research in the field of clinical decision-making should foster the use of patient and physician versions of a similar instrument. In line with the growing interest for shared decision-making, this may allow for a more comprehensive assessment of the complexity of the clinical decisionmaking process and thus of its dynamic and reciprocal nature [65].

Third, this review highlights the need for further methodological development in studies assessing the perception of physicians of the decision-making process within specific clinical encounters. None of the authors of the included instruments provided data on the responsiveness of their instruments (i.e. the extent to which the instrument measures physician change over time). Also, 'within physician' clustering of multiple data points (i.e. non-independence of data) produced statistical challenges that were dealt with inconsistently by their developers. In one instrument, clustering of multiple data point under each physician was taken into account for the factorial analysis but not for the reliability analyses $[84,85]$. 
Table 3: Quality assessment of the studies that reported on the included instruments based on the modified version of STARD * For this instrument, only one publication in English was found. This publication reported on the study of physicians that had used the instrument. Other publications pertaining to this instrument were in German

\begin{tabular}{|c|c|c|c|c|c|c|c|c|c|c|c|c|}
\hline Section and Topic & Item & {$[83]$} & {$[56]$} & {$[72]$} & [84] & {$[50]$} & [61] & {$[65]$} & [8I] & {$[68]$} & {$[73]^{*}$} & [58] \\
\hline $\begin{array}{l}\text { TITLE/ } \\
\text { ABSTRACT }\end{array}$ & $\begin{array}{l}\text { Identify the article as a study concerning a } \\
\text { measuring instrument. }\end{array}$ & + & + & + & + & + & + & + & + & + & 0 & + \\
\hline INTRODUC-TON & $\begin{array}{l}\text { State the research questions or study aims, like } \\
\text { developing or validating a measuring instrument. }\end{array}$ & + & + & + & + & + & + & + & + & + & 0 & + \\
\hline \multicolumn{13}{|c|}{ 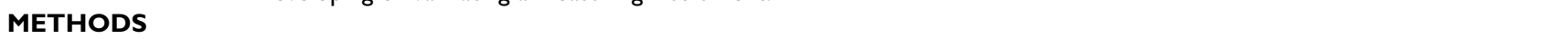 } \\
\hline \multirow[t]{4}{*}{ Participants } & $\begin{array}{l}\text { Describe the study population: The inclusion and } \\
\text { exclusion criteria, setting and locations where the } \\
\text { data were collected. }\end{array}$ & + & + & + & + & + & + & + & + & + & 0 & + \\
\hline & $\begin{array}{l}\text { Describe the method of recruitment of the } \\
\text { participants. }\end{array}$ & 0 & 0 & 0 & + & 0 & 0 & 0 & + & + & 0 & + \\
\hline & $\begin{array}{l}\text { Describe participant sampling: Was the study } \\
\text { population a consecutive series of participants } \\
\text { defined by the selection criteria in items } 3 \text { and } 4 \text { ? If } \\
\text { not, specify how participants were further } \\
\text { selected. }\end{array}$ & 0 & 0 & 0 & 0 & 0 & + & 0 & + & + & 0 & + \\
\hline & $\begin{array}{l}\text { Describe data collection: Was data collection } \\
\text { planned before the use of the measuring } \\
\text { instrument? }\end{array}$ & 0 & 0 & 0 & + & 0 & + & 0 & + & 0 & 0 & + \\
\hline \multirow[t]{5}{*}{ Test methods } & $\begin{array}{l}\text { Describe the reference standard criterion validity } \\
\text { and its rationale. }\end{array}$ & 0 & 0 & 0 & 0 & 0 & 0 & 0 & + & 0 & + & 0 \\
\hline & $\begin{array}{l}\text { Describe technical specifications of material and } \\
\text { methods involved including how and when } \\
\text { measurements were taken, and/or cite references } \\
\text { for measuring instrument. }\end{array}$ & + & + & + & + & + & + & + & + & + & 0 & + \\
\hline & $\begin{array}{l}\text { Describe definition of and rationale for the units, } \\
\text { cut-offs and/or categories of the results of the } \\
\text { instrument and the reference standard. }\end{array}$ & + & + & + & + & + & + & + & + & + & 0 & 0 \\
\hline & $\begin{array}{l}\text { Describe the number, training and expertise of the } \\
\text { persons executing and reading the measuring } \\
\text { instrument and the reference standard. }\end{array}$ & 0 & 0 & 0 & + & 0 & 0 & 0 & 0 & 0 & 0 & 0 \\
\hline & $\begin{array}{l}\text { Describe other tests or relevant information for } \\
\text { the readers concerning the measuring instrument } \\
\text { (subjective). }\end{array}$ & + & + & + & + & + & + & + & + & + & + & + \\
\hline \multirow[t]{3}{*}{ Statistical methods } & $\begin{array}{l}\text { Describe methods for calculating or comparing } \\
\text { measures of reliability, validity, and the statistical } \\
\text { methods used to quantify uncertainty (e.g. } 95 \% \\
\text { confidence intervals) }\end{array}$ & + & + & 0 & + & + & 0 & + & + & + & 0 & + \\
\hline & $\begin{array}{l}\text { Describe methods for calculating test } \\
\text { reproducibility, if done. }\end{array}$ & 0 & 0 & 0 & 0 & 0 & 0 & + & 0 & 0 & 0 & + \\
\hline & $\begin{array}{l}\text { Describe a method that takes into account } \\
\text { non-independence of data (if applicable) }\end{array}$ & 0 & + & 0 & + & + & 0 & + & 0 & 0 & 0 & 0 \\
\hline \multicolumn{13}{|l|}{ RESULTS } \\
\hline \multirow[t]{3}{*}{ Participants } & $\begin{array}{l}\text { Report when study was done, including beginning } \\
\text { and ending dates of recruitment. }\end{array}$ & 0 & 0 & 0 & 0 & 0 & 0 & 0 & + & + & 0 & 0 \\
\hline & $\begin{array}{l}\text { Report demographic characteristics of the study } \\
\text { population (e.g. age, sex, employment, recruitment } \\
\text { centers). }\end{array}$ & + & + & + & + & + & + & 0 & + & + & 0 & + \\
\hline & $\begin{array}{l}\text { Report the number of participants satisfying the } \\
\text { criteria for inclusion (a flow diagram is strongly } \\
\text { recommended). }\end{array}$ & 0 & 0 & 0 & 0 & 0 & 0 & 0 & + & + & 0 & + \\
\hline \multirow[t]{2}{*}{ Test results } & $\begin{array}{l}\text { Report time interval from the measuring } \\
\text { instrument to the reference standard, and any } \\
\text { measures administered in between. }\end{array}$ & 0 & 0 & 0 & 0 & 0 & 0 & 0 & + & 0 & 0 & 0 \\
\hline & Report distribution of severity of the situation & 0 & 0 & 0 & 0 & 0 & 0 & 0 & 0 & 0 & 0 & 0 \\
\hline
\end{tabular}


Table 3: Quality assessment of the studies that reported on the included instruments based on the modified version of STARD * For this instrument, only one publication in English was found. This publication reported on the study of physicians that had used the instrument. Other publications pertaining to this instrument were in German (Continued)

\begin{tabular}{|c|c|c|c|c|c|c|c|c|c|c|c|c|}
\hline & $\begin{array}{l}\text { Report a cross tabulation of the results of the } \\
\text { measuring instrument (including indeterminate and } \\
\text { missing results) by the results of the reference } \\
\text { standard; for continuous results, the distribution } \\
\text { of the test results by the results of the reference } \\
\text { standard }\end{array}$ & + & 0 & + & + & + & + & + & + & + & 0 & 0 \\
\hline & $\begin{array}{l}\text { Report any adverse events from performing the } \\
\text { measuring instrument or the reference standard }\end{array}$ & 0 & 0 & 0 & 0 & 0 & 0 & 0 & 0 & 0 & 0 & 0 \\
\hline \multirow[t]{4}{*}{ Estimates } & $\begin{array}{l}\text { Report estimates of accuracy and measures of } \\
\text { statistical uncertainty } \\
\text { (e.g. } 95 \% \text { confidence intervals). }\end{array}$ & + & + & + & + & 0 & + & + & + & + & 0 & 0 \\
\hline & $\begin{array}{l}\text { Report how indeterminate results, missing } \\
\text { responses and outliers of the measuring } \\
\text { instrument were handled. }\end{array}$ & 0 & 0 & 0 & 0 & 0 & + & + & 0 & 0 & 0 & 0 \\
\hline & $\begin{array}{l}\text { Report estimates of variability of accuracy } \\
\text { between groups of participants, if done. }\end{array}$ & 0 & 0 & + & + & 0 & 0 & + & 0 & 0 & 0 & + \\
\hline & Report estimates of test reproducibility, if done. & 0 & 0 & 0 & 0 & 0 & 0 & + & 0 & 0 & 0 & + \\
\hline \multirow[t]{2}{*}{ DISCUSSION } & $\begin{array}{l}\text { Discuss the clinical applicability of the study } \\
\text { findings. }\end{array}$ & + & + & + & + & + & + & + & + & + & 0 & + \\
\hline & & $\begin{array}{l}11 / \\
26\end{array}$ & $\begin{array}{l}11 / \\
26\end{array}$ & $\begin{array}{l}11 / \\
26\end{array}$ & $\begin{array}{l}16 / \\
26\end{array}$ & $\begin{array}{l}11 / \\
26\end{array}$ & $\begin{array}{l}13 / \\
26\end{array}$ & $\begin{array}{l}15 / \\
26\end{array}$ & $\begin{array}{l}18 / \\
26\end{array}$ & $\begin{array}{l}15 / \\
26\end{array}$ & $\begin{array}{c}2 / \\
26^{*}\end{array}$ & $\begin{array}{l}14 / \\
26\end{array}$ \\
\hline
\end{tabular}

* For this instrument, only one publication in English was found. This publication reported on the study of physicians that had used the instrument. Other publications pertaining to this instrument were in German.

Authors who took clustering into consideration used one of three strategies: average score per physician $[55,56,59,74]$, one data entry per physician $[47-53,75]$ or bootstrapping [57,64-67,69-71,84,85]. Therefore, methodological development in this area will be needed to ensure that responsive instruments and adequate analytical approaches are used in studies assessing the perception of physicians of the decision-making process within specific clinical encounters.

Lastly, for the included instruments, the mean number of items ranged from 6 to 37 items ( mean $=16.7$ ). It remains a challenge for health service researchers to develop sound measurements for conducting implementation studies that will minimize the burden to participating physicians. In our own experience, and in line with what has been reported in the literature, there appears to be an association between instrument length, defined in this systematic review as the number of items included in an instrument, and physician participation in studies [94]. This is perhaps even more apparent for health professionals' selfadministered questionnaires after a specific clinical encounter. As such, our results provide some valuable insight or benchmarking about the number of items included in the instruments that are currently available for conducting studies on clinical decision-making with physicians.

This review has a number of limitations. Studies reporting the development of instruments are generally not wellindexed in electronic databases [95]. In this review, the search strategies used may not have been optimal even though we consulted with three experienced information specialists. It is possible that some eligible instruments as well as relevant publication regarding the included instruments were not included in this review. Also, clinical decision-making is moving from a unidisciplinary perspective to an interdisciplinary perspective [20]. Therefore, the included instruments might not be representative of ongoing developments in healthcare decision-making. Indeed, recent health services policy documents clearly indicate the need for patient-centered care provided by an interprofessional team [96]. However, in a review on barriers and facilitators to implementing shared decision making in clinical practice as perceived by health professionals, the vast majority of participants $(n=2784)$ enrolled in the 28 included studies were physicians (89\%) [97]. This suggests that more will need to be done to enhance an interprofessional perspective to shared decision making, a process by which a patient and his/her healthcare providers engage in a decision-making process. We firmly believe that the instruments that were identified throughout this review could be further developed using this interprofessional perspective.

Lastly, it is interesting to note that for the eleven included instruments, the mean score of items on the STARD was 12.4 (range: 2 to 18 ). It is important to emphasize that seven of the included instruments were published before the 2003 STARD criteria. Although, this mean score compared well to the mean scores of items on the STARD that were reported in test accuracy studies in reproductive 
medicine: 12.1, future research in this field will need to improve the reporting of the development of instruments that would assess healthcare professional's perspective of the decision-making process

\section{Conclusion}

This systematic review provides valuable data on instruments that assess the perception of physicians of the decision-making process within specific clinical encounters. It can be used by educators and health services researchers as a repository of standardized measures of the physician perspective of the clinical decision-making process and we hope of other healthcare providers. It was not our intention to identify the "best" instrument but rather to offer options to the target audience. We believe that based on the context of its intended use, a process of weighting its limitations and strengths and other factors faced by its potential users, most if not all of the identified instruments might play a valuable role in the future. This systematic review also sent an important signal: in the XXI century, the clinical decision-making process might only be adequately assessed by using a dyadic approach. In this regard, some of the identified instruments might be more attractive than others. However, more research is needed to investigate the validation of these instruments. More specifically, for the production of evidence on the validity and reliability data of the instruments, analytical methods that take into account within physician clustering is required. For all the included instruments, the development of corresponding patient versions should be encouraged. The combined use of the patient version with its respective healthcare professional version will help capture the complexity of the clinical decision-making process and thus of its dynamic and reciprocal nature. Only then will a new and more comprehensive understanding of health-related decision-making in the context of specific clinical encounters be possible.

\section{Competing interests}

All author(s) declare that they have no conflicting financial interests.

One of the authors (FL) is an author of three of the included studies.

\section{Authors' contributions}

FL conceived the study, supervised KG and AL, validated the methods, validated the article selection, abstracted all included instruments, analysed the results, and wrote the paper. KG participated in the selection of the articles and abstracted all included instruments. KG and AL assessed the quality of the included studies and reviewed the paper. DM participated in the conception of the review, provided comments on the search strategy, validated the methods and reviewed the paper. GE validated the methods, partic- ipated in the interpretation of the results and reviewed the paper. All authors have read and approved the final version of the manuscript. FL is its guarantor.

\section{Acknowledgements}

We thank all the authors who were contacted and who provided us with assistance. We also thank M. Marc-André Morin, a student in psychology, who contributed to an earlier draft of the protocol and first identification of eligible instruments. We acknowledge the contribution of Margaret Sampson, Alexandra Davis and Stéphane Ratté for helping to design, update and run the search strategy. Dr. Légaré is supported by a Canada Research Chair in Implementation of Shared Decision Making in Primary Care, Université Laval and CanGenetest. Dr. Moher is supported by a University of Ottawa Research Chair.

\section{References}

I. McWhinney IR: A Textbook of Family Medicine. 2nd edition. New York - Oxford: Oxford University Press; 1997.

2. Gale J, Marsden P: Diagnosis: Process not Product. In Decisionmaking in General Practice Edited by: Sheldon M, Brooke J, Rector A. New-York: Stockton Press; 1985:59-90.

3. Chapman GB, Sonnenberg FA: Decision Making in Health Care. Theory, Psychology, and Applications. Cambridge: Cambridge University Press; 2000.

4. Fish D, Coles C: Developing Professional Judgement in Health Care. Learning through the critical appreciation of practice. Butterworth-Heinemann 1998.

5. Charles C, Gafni A, Whelan T: Shared decision-making in the medical encounter: what does it mean? (or it takes at least two to tango). Soc Sci Med 1997, 44:681-92.

6. Elwyn G, Edwards A, Kinnersley P, Grol R: Shared decision making and the concept of equipoise: the competences of involving patients in healthcare choices. Br J Gen Pract 2000, 50:892-9.

7. Towle A, Godolphin W: Framework for teaching and learning informed shared decision making. BMJ 1999, 3 I 9:766-7I.

8. Elwyn G, Edwards A, Kinnersley P: Shared decision-making in primary care: the neglected second half of the consultation. $\mathrm{Br} J$ Gen Pract 1999, 49:477-82.

9. Briss P, Rimer B, Reilley B, Coates RC, Lee NC, Mullen P, Corso P, Hutchinson AB, Hiatt R, Kerner J, George P, White C, Gandhi N, Saraiya M, Breslow R, Isham G, Teutsch SM, Hinman AR, Lawrence R: Promoting informed decisions about cancer screening in communities and healthcare systems. Am J Prev Med 2004, 26:67-80.

10. Makoul G, Arntson P, Schofield T: Health promotion in primary care: physician-patient communication and decision making about prescription medications. Soc Sci Med 1995, 4 I: 124 |-54.

II. Di lorio CK: Measurement in health behavior. Methods for research and evaluation. Ist edition. San Francisco: Josey-Bass; 2005.

12. McDowell I, Newell C: Measuring Health. A guide to rating scales and questionnaires. 2nd edition. New York: Oxford University Press; 1987.

13. Fawcett J: Conceptual Models and Theories. In Analysis and Evaluation of Conceptual Models of Nursing 2nd edition. Philadelphia (PA): F.A. Davis Company; 1989: I-40.

14. Streiner DL, Norman GR: Health Measurements Scales. A practical guide to their development and use. Oxford: Oxford University Press; 1995.

15. Guyatt G, Walter S, Norman G: Measuring change over time: assessing the usefulness of evaluative instruments. J Chronic Dis 1987, 40:|7|-8.

16. Bossuyt PM, Reitsma JB: The STARD initiative. Lancet 2003, 36I:7I.

17. Bossuyt PM, Reitsma JB, Bruns DE, Gatsonis CA, Glasziou PP, Irwig LM, Moher D, Rennie D, de Vet HC, Lijmer JG: The STARD statement for reporting studies of diagnostic accuracy: explanation and elaboration. Ann Intern Med 2003, I38:WI-I 2.

18. Meyer G]: Guidelines for reporting information in studies of diagnostic test accuracy: the STARD initiative. Journal of Personality Assessment 2003, 81:191-3. 
19. Ashworth CD, Williamson P, Montano D: A scale to measure physician beliefs about psychosocial aspects of patient care. Soc Sci Med 1984, 19:1235-8.

20. Baggs JG: Two instruments to measure interdisciplinary bioethical decision making. Heart Lung 1993, 22:542-7.

21. Bates AS, Harris LE, Tierney WM, Wolinsky FD: Dimensions and correlates of physician work satisfaction in a midwestern city. Med Care 1998, 36:610-17.

22. de Monchy C, Richardson R, Brown R, Harden R: Measuring attitudes of doctors: the doctor-patient (DP) rating. Med Educ 1988, 22:231-9.

23. Garcia-Pena C, Reyes-Frausto S, Reyes-Lagunes I, Munoz Hernandez $O$ : Family physician job satisfaction in different medical care organization models. Family Practice 2000:309-I3

24. Garcia-Pena C, Reyes-Lagunes I, Reyes-Frausto S, Villa-Contreras S, Libreros-Bango V, Munoz Hernandez O: Development and Validation of an Inventory for Measuring Job Satisfaction among Family Physicians. Psychological Reports 1996, 79:291-301.

25. Geller G, Tambor ES, Chase GA, Holtzman NA: Measuring physicians' tolerance for ambiguity and its relationship to their reported practices regarding genetic testing. Med Care 1993 , 3 I:989-1001

26. Gerrity MS, DeVellis RF, Earp JA: Physicians' reactions to uncertainty in patient care. A new measure and new insights. Med Care 1990, 28:724-36.

27. Gerrity MS, Earp JAL, De Vellis RF, Light DW: Uncertainty and Professional Work: Perceptions of Physicians in Clinical Practice. Am J Sociology 1992, 97: 1022-51.

28. Hojat M, Fields S, Veloski J, Griffiths M, Cohen M, Plumb J: Psychometric properties of an attitude scale measuring physiciannurse collaboration. Eval Health Prof 1999, 22:208.

29. Hojat M, Gonnella J, Nasca T, Fields S, Cicchetti A, Lo Scalzo A, Taroni F, Amicosante A, Macinati M, Tangucci M, Liva C, Ricciardi G Eidelman S, Admi H, Geva H, Mashiach T, Alroy G, Alcorta-Gonzalez A, Ibarra D, Torres-Ruiz A: Comparisons of American, Israeli, Italian and Mexican physicians and nurses on the total and factor scores of the Jefferson scale of attitudes toward physician-nurse collaborative relationships. Int J Nurs Stud 2003 , 40:427-35.

30. Hojat M, Gonnella J, Nasca T, Mangione S, Veloksi J, Magee M: The Jefferson Scale of Physician Empathy: further psychometric data and differences by gender and specialty at item level. Acad Med 2002, 77:S58-60.

31. Hojat M, Nasca T, Cohen M, Fields S, Rattner S, Griffiths M, Ibarra D, de Gonzalez A, Torres-Ruiz A, Ibarra G, Garcia A: Attitudes toward physician-nurse collaboration: a cross-cultural study of male and female physicians and nurses in the United States and Mexico. Nurs res 200I, 50:123-8.

32. Holtgrave DR, Lawler F, Spann SJ: Physicians' risk attitudes, laboratory usage, and referral decisions: the case of an academic family practice center. Med Decis Making 1991, I I: | 25-30.

33. Konrad TR, Williams ES, Linzer M, McMurray J, Pathman DE, Gerrity M, Schwartz MD, Scheckler WE, Van Kirk J, Rhodes E, Douglas J: Measuring physician job satisfaction in a changing workplace and a challenging environment. SGIM Career Satisfaction Study Group. Society of General Internal Medicine. Med Care 1999, 37: $1174-82$.

34. Krupat E, Rosenkranz SL, Yeager CM, Barnard K, Putman S, Inui TS The practice orientations of physicians and patients: the effect of doctor-patient congruence on satisfaction. Patient Educ Couns 2000, 39:49-59.

35. Levinson W, Roter D: Physicians' psychosocial beliefs correlate with their patient communication skills. J Gen Intern Med I995, 10:375-79.

36. Linn LS, DiMatteo MR, Cope DW, Robbins A: Measuring physicians' humanistic attitudes, values, and behaviors. Med Care 1987, 25:504-I5.

37. Linzer M, Konrad TR, Douglas J, McMurray JE, Pathman DE, Williams ES, Schwartz MD, Gerrity M, Scheckler W, Bigby JA, Rhodes E: Managed care, time pressure, and physician job satisfaction: results from the physician worklife study. I Gen Intern Med 2000, I 5:44I-50.

38. Maheux C, Beaudoin C, Jean P, DesMarchais J, Cote L, M Tiraoui A: Development and validation of a measure of patient-centered care in medical practice. 1993.
39. Markert RJ: Cross-cultural validation of the Doctor-Patient Scale. Acad Med 1989, 64:690.

40. Park HS, Lee SH, Shim JY, Cho JJ, Shin HC, Park JY: The physicians' recognition and attitude about patient education in practice. Journal of Korean Medical Science 1996, I I:422-28.

4I. Pearson SD, Goldman L, Orav EJ, Guadagnoli E, Garcia TB, Johnson PA, Lee TH: Triage decisions for emergency department patients with chest pain: do physicians' risk attitudes make the difference? J Gen Intern Med 1995, 10:557-64.

42. Scheckler WE, Schulz R, Moberg P: Physician satisfaction with the development of HMOs in Dane County: 1983-1993. Wis Med J 1994, 93:444-6.

43. Stiggelbout AM, Molewijk AC, Otten W, Timmermans DR, van Bockel $\mathrm{JH}$, Kievit J: Ideals of patient autonomy in clinical decision making: a study on the development of a scale to assess patients' and physicians' views. J Med Ethics 2004, 30:268-74.

44. Williams ES, Konrad TR, Linzer M, McMurray J, Pathman DE, Gerrity M, Schwartz MD, Scheckler WE, Van Kirk J, Rhodes E, Douglas J: Refining the measurement of physician job satisfaction: results from the Physician Worklife Survey. SGIM Career Satisfaction Study Group. Society of General Internal Medicine. Med Care 1999, 37: I |40-54.

45. Yildirim A, Akinci $F$, Ates $M$, Ross $T$, Issever $H$, Isci $E$, Selimen $D$ Turkish version of the Jefferson Scale of Attitudes Toward Physician-Nurse Collaboration: a preliminary study. Contemp Nurse 2006, 23:38-45.

46. Zandbelt LC, Smets EMA, Oort FJ, Godfried MH, de Haes HCJM: Satisfaction with the Outpatient Encounter: A Comparison of Patients' and Physicians' Views. J Gen Intern Med 2004, 19:1088-95.

47. Baggs JG, Ryan SA: ICU nurse-physician collaboration \& nursing satisfaction. Nursing economic\$1990, 8:386-92.

48. Baggs JG, Schmitt MH: Intensive care decisions about level of aggressiveness of care. Res Nurs Health 1995, I 8:345-55.

49. Baggs J: Psychometric evaluation of collaboration and satisfaction about care decision (CSACD) instrument. Heart \& Lung 1992, 21:296.

50. Baggs JG: Development of an instrument to measure collaboration and satisfaction about care decisions. J Adv Nurs 1994 20: $176-82$.

5I. Baggs JG, Ryan SA, Phelps CE, Richeson JF, Johnson JE: The association between interdisciplinary collaboration and patient outcomes in a medical intensive care unit. Heart \& Lung 1992, 2 I : |8-24.

52. Baggs JG, Schmitt MH, Mushlin Al, Mitchell PH, Eldredge DH, Oakes $D$, Hutson AD: Association between nurse-physician collaboration and patient outcomes in three intensive care units. Critical Care Medicine 1999, 27:1991-98.

53. Baggs JG, Schmitt MH, Mushlin AL, Eldredge DH, Oakes D, Hutson AD: Nurse-physician collaboration and satisfaction with the decision-making process in three critical care units. Am / Crit Care 1997, 6:393-99.

54. Barnett D, Bass P, Griffith C, Caudill S, Wilson J: Determinants of resident satisfaction with patients in their continuity clinic. J Gen Intern Med 2004, 19:456-59.

55. Bertram DA, Hershey CO, Opila DA, Quirin O: A measure of physician mental work load in internal medicine ambulatory care clinics. Med Care 1990, 28:458-67.

56. Bertram DA, Opila DA, Brown JL, Gallagher SJ, Schifeling RW, Snow IS, Hershey CO: Measuring physician mental workload: reliability and validity assessment of a brief instrument. Med Care 1992, 30:95-104.

57. Brothers TE, Cox MH, Robison JG, et al:: Prospective decision analysis modeling indicates that clinical decisions in vascular surgery often fail to maximize patient expected utility. J Surg Research 2004, I 20:278-87

58. Campbell $\mathrm{C}$, Lockyer J, Laidlaw T, Macleod $\mathrm{H}$ : Assessment of a matched-pair instrument to examine doctor-patient communication skills in practising doctors. Med Educ 2007, 4I:|23-9.

59. Carayon P, Hundt AS, Alvarado CJ, Springman SR, Ayoub P: Patient safety in outpatient surgery: the viewpoint of the healthcare providers. Ergonomics 2006, 49:470-85.

60. Cegala D, McNeilis K, Socha McGee D, Jonas A: A study of doctor's and patient's perceptions of information processing and 
communication competence during the medical interview. Health Commun 1995, 2:179-203.

6I. Cegala DJ, Coleman MT, Turner JW: The development and partial assessment of the medical communication competence scale. Health Commun 1998, 10:261-88.

62. Cegala DJ, Gade C, Lenzmeier Broz S, McClure L: Physicians' and Patients' Perceptions of Patients' Communication Competence in a Primary Care Medical Interview. Health Commun 2004, 16:289-304

63. Cegala DJ, Socha McGee D, McNeilis KS: Components of Patients' and Doctors' Perceptions of Communication Competence During a Primary Care Medical Interview. Health Commun 1996, 8: I-27.

64. Dolan JG, Riggs AT, Gracey CF, Howard FM: Initial evaluation of the provider decision process assessment instrument (PDPAI): A process-based method for assessing the quality of health providers' decisions. Annual Meeting of the Society for Medical Decision Making: 1995: Med Dec Making; 1995:429.

65. Dolan JG: A method for evaluating health care providers' decision making: the Provider Decision Process Assessment Instrument. Med Decis Making 1999, 19:38-4I.

66. Gattellari M, Donnelly N, Taylor N, Meerkin M, Hirst G, Ward JE: Does 'peer coaching' increase GP capacity to promote informed decision making about PSA screening? A cluster randomised trial. Family Practice 2005, 22:253-65.

67. Guimond P, Bunn H, O'Connor AM, Jacobsen MJ, Tait VK, Drake ER, Graham ID, Stacey D, Elmslie T: Validation of a tool to assess health practitioners' decision support and communication skills. Patient Educ Couns 2003, 50:235-45.

68. Harmsen JA, Bernsen RM, Meeuwesen L, Pinto D, Bruijnzeels MA: Assessment of mutual understanding of physician patient encounters: development and validation of a Mutual Under standing Scale (MUS) in a multicultural general practice setting. Patient Educ Couns 2005, 59: I7|-8I.

69. Légaré F, O'Connor AM, Graham ID, Wells GA, Tremblay S: Impact of the Ottawa Decision Support Framework on the agreement and the difference between patients' and physicians' decisional conflict. Med Decis Making 2006, 26:373-90.

70. Légaré F, O'Connor A, Graham I, Wells G, Jacobsen MJ, Elmslie T, Drake $E$ : The effect of decision aids on the agreement between women's and physician's decisional conflict about hormone replacement therapy. Patient Educ Couns 2003, 50:2II-2I

7I. Légaré F, Tremblay S, O'Connor AM, Graham ID, Wells GA, Jacobsen MJ: Factors associated with the difference in score between women's and doctors' decisional conflict about hormone therapy: a multilevel regression analysis. Health Expect 2003, 6:208-21

72. Levinson W, Stiles WB, Inui TS, Engle R: Physician frustration in communicating with patients. Med Care 1993, 31:285-95.

73. Linden M, Pyrkosch L, Dittmann RFW, Czekalla J: Why do physicians switch from one antipsychotic agent to another? - The "Physician drug stereotype". Journal of clinical psychopharmacology 2006, 26:225-3I.

74. Margalit AP, Glick SM, Benbassat J, Cohen A, Katz M: Promoting a biopsychosocial orientation in family practice: effect of two teaching programs on the knowledge and attitudes of practising primary care physicians. Medical Teacher 2005, 27:6 13-18.

75. Moore-Smithson J: The association between nurse-physician collaboration and satisfaction with the decision-making process in the ambulatory care setting. M.S. United States New York: D'Youville College; 2005.

76. Newes-Adeyi G, Helitzer DL, Roter D, Caulfield LE: Improving client-provider communication: evaluation of a training program for women, infants and children (WIC) professionals in New York state. Patient Educ Couns 2004, 55:210-7.

77. Dobkin PL, De Civita M, Abrahamowicz M, Bernatsky S, Schulz J, Sewitch M, Baron M: Patient-physician discordance in fibromyalgia. J Rheumatol 2003, 30:1326-34.

78. Dobkin PL, Sita A, Sewitch MJ: Predictors of adherence to treatment in women with fibromyalgia. Clinical Journal of Pain 2006, 22:286-94

79. Sewitch M: Effect of discordant physician-patient perceptions on patient adherence in inflammatory bowel disease. In Doc toral Dissertation Montreal: McGill University; 2001.
80. Sewitch MJ, Abrahamowicz M, Barkun A, Bitton A, Wild GE, Cohen A, Dobkin PL: Patient nonadherence to medication in inflammatory bowel disease. Am J Gastroenterol 2003, 98: I 535-44.

8I. Sewitch MJ, Abrahamowicz M, Dobkin PL, Tamblyn R: Measuring differences between patients' and physicians' health perceptions: the patient-physician discordance scale. I Behav Med 2003, 26:245-64.

82. Sewitch MJ, Dobkin PL, Bernatsky S, Baron M, Starr M, Cohen M, Fitzcharles MA: Medication non-adherence in women with fibromyalgia. Rheumatology 2004, 43:648-54.

83. Shore BE, Franks P: Physician satisfaction with patient encounters. Reliability and validity of an encounter-specific questionnaire. Med Care 1986, 24:580-9.

84. Suchman AL, Roter D, Green M, Lipkin MJr: Physician satisfaction with primary care office visits. Collaborative Study Group of the American Academy on Physician and Patient. Med Care 1993, 3 I: I083-92.

85. Sullivan MD, Leigh J, Gaster B: Brief report: Training internists in shared decision making about chronic opioid treatment for noncancer pain. I Gen Intern Med 2006, $21: 360-2$.

86. Hakkennes S, Green S: Measures for assessing practice change in medical practitioners. Implement Sci 2006, I:29.

87. Grol R, Leatherman S: Improving quality in British primary care: seeking the right balance. $\mathrm{Br} J$ Gen Pract 2002, 52(Suppl):S3-4.

88. Grol R, Grimshaw J: From best evidence to best practice: effective implementation of change in patients' care. Lancet 2003, 362:1225-30.

89. Eccles M, Grimshaw J, Walker A, Johnston M, Pitts N: Changing the behavior of healthcare professionals: the use of theory in promoting the uptake of research findings. I Clin Epidemiol 2005, 58:107-12.

90. Hardeman W, Johnston M, Johnston DW, Bonetti D, Wareham NJ, Kinmonth AL: Application of the Theory of Planned Behaviour in Behaviour Change Interventions: a Systematic Review. Psychology and Health 2002, 17:123-58.

91. Kashy DA, Kenny DA: The analysis of data from dyads and groups. In Handbook of research methods in social and personality psychology Edited by: Reis HT, Judd CM. New York: Cambridge University Press; 2000:45I-77.

92. Kenny DA, Cook W: Partner effects in relationship research: Conceptual issues, analytic difficulties, and illustrations. Personal Relationships 1999, 6:433-48.

93. Suchman AL: A new theoretical foundation for relationshipcentered care. Complex responsive processes of relating. Gen Intern Med 2006, 21 :S40-4.

94. Jepson C, Asch DA, Hershey JC, Ubel PA: In a mailed physician survey, questionnaire length had a threshold effect on response rate. J Clin Epidemiol 2005, 58:103-5.

95. Elwyn G, Edwards A, Mowle S, Wensing M, Wilkinson C, Kinnersley $P$, Grol R: Measuring the involvement of patients in shared decision-making: a systematic review of instruments. Patient Educ Couns 200I, 43:5-22.

96. Curran VR, Deacon DR, Fleet L: Academic administrators' attitudes towards interprofessional education in Canadian schools of health professional education. J Interprof Care 2005, I 9(Suppl I):76-86

97. Gravel K, Legare F, Graham ID: Barriers and facilitators to implementing shared decision-making in clinical practice: A systematic review of health professionals' perceptions. Implement Sci 2006, I:16.

98. Stewart M, Belle Brown J, Weston W, McWhinney IR, McMillan CL, Freeman TR: Patient-Centered Medicine. Transforming the Clinical Method. London: Sage Publications; 1995.

\section{Pre-publication history}

The pre-publication history for this paper can be accessed here:

http://www.biomedcentral.com/1472-6947/7/30/prepub 